\title{
ANALISIS FAKTOR UTAMA KADAR TRIGLISERIDA ABNORMAL PADA PENDUDUK DEWASA DI INDONESIA
}

\author{
Mukhlidah Hanun Siregar ${ }^{1}$, Fatmah $^{2}$, RAD Sartika ${ }^{3}$ \\ ${ }^{1}$ Fakultas Kedokteran Universitas Sultan Ageng Tirtayasa \\ ${ }^{2 \& 3}$ Fakultas Kesehatan Masyarakat Universitas Indonesia \\ Email: mukhlidah.hanunsiregar@untirta.ac.id
}

\begin{abstract}
Triglycerides is a compound consisting of three molecule fatty acid, synthesized from carbohydrates and deposited as animal fats in the body. Finding suggests that elevated levels of triglyceride were one of the risks of cardiovascular disease. Hypertriglyceridemia can lead to increased LDL cholesterol and lower HDL cholesterol, which became an indicator of cardiovascular disease. Previous finding found that age, sex, obesity, fatty food, coffee, and smoking associated with triglycerides. The aims of this study to identify the main factor associated with the levels of triglyceride in Indonesian adult (26-45 years). Data taken from secondary data Basic Health Reseach (RISKESDAS) with the specific criteria. The total respondents were 11421. Data analyzed with logistics multiple regression prediction model. The results showed $23.2 \%$ of respondents have abnormal levels of triglyceride $(150 \mathrm{mg} / \mathrm{dl})$. The main factors associated with the abnormal levels of triglyceride were sex $[O R=3,215(2,745-3,765)]$, central obesity $[O R=2,664(2,393$ 2,967)], and smoking [OR $=1,222(1,048-1,426)]$. Finding suggested keeping healthy lifestyle so not to be central obesity, especially men. In addition, leave cigarettes by reducing the number of cigarettes every day gradually, can decrease the abnormal levels of triglyceride.
\end{abstract}

Keywords: Triglycerides, Sex, Central Obesity, Smoking, Adult

\begin{abstract}
Abstrak
Trigliserida merupakan senyawa yang terdiri dari 3 molekul asam lemak, disintesis dari karbohidrat dan disimpan sebagai lemak hewani dalam tubuh. Temuan menegaskan bahwa peningkatan kadar trigliserida dalam darah merupakan salah satu faktor risiko dari penyakit kardiovaskular. Hipertrigliseridemia dapat menyebabkan peningkatan LDL Kolesterol dan penurunan HDL Kolesterol yang menjadi indikator penyakit kardiovaskular. Penelitian sebelumnya menemukan bahwa usia, jenis kelamin, kegemukan, makanan berlemak, kopi, dan merokok berhubungan dengan trigliserida. Studi ini bertujuan untuk mengidentifikasi faktor utama yang berhubungan dengan kadar trigliserida pada penduduk dewasa (26-45 tahun) di Indonesia. Data diambil dari data sekunder yang berasal dari Riset Kesehatan Dasar (RISKESDAS) dengan kriteria khusus. Total responden sebanyak 11421. Data dianalisis menggunakan uji Regresi Logistik Berganda model prediksi. Hasil penelitian menunjukkan 23,2\% responden memiliki kadar trigliserida tidak normal $(>150 \mathrm{mg} / \mathrm{dl})$. Faktor utama yang berhubungan dengan kadar trigliserida tidak normal tersebut adalah jenis kelamin $[O R=3,215(2,745-3,765)]$, obesitas sentral $[O R=2,664(2,393-2,967)]$, dan merokok $[\mathrm{OR}=1,222(1,048-1,426)]$. Hasil temuan ini menyarankan kepada penduduk dewasa untuk menjaga gaya hidup sehat agar tidak mengalami obesitas sentral, utamanya kelompok laki- laki. Selain itu, meninggalkan rokok dengan mengurangi jumlah rokok yang dikonsumsi setiap harinya secara bertahap sehingga terjadi penurunan kadar trigliserida yang tidak normal.
\end{abstract}

Kata kunci: Trigliserida, jenis kelamin, obesitas sentral, merokok, dewasa 


\section{PENDAHULUAN}

Trigliserida merupakan senyawa yang terdiri dari 3 molekul asam lemak yang teresterisasi menjadi gliserol, disintesis dari karbohidrat dan disimpan dalam bentuk lemak hewani. Dalam serum dibawa oleh lipoprotein dan merupakan penyebab utama penyakit arteri dibanding kolesterol. Hipertrigliserida akan berdampak kepada risiko kejadian penyakit jantung koroner/PJK (Baig et al., 2015).

Terjadi peningkatan kadar trigliserida di Amerika Serikat pada survei di tahun 19761980 dan 1999-2002. Dan secara keseluruhan pada tahun 1999-2008 terdapat survei yang menunjukkan bahwa $31 \%$ penduduk dewasa di AS memiliki kadar trigliserida $\geq 150$ $\mathrm{mg} / \mathrm{dl}$. Pada 20 tahun terakhir, peningkatan kadar trigliserida hanya sedikit pada kelompok lanjut usia, namun yang menjadi temua ada- lah bahwa terjadi peningkatan kadar trigliserida pada kelompok yang lebih muda yaitu usia 20-49 tahun (Miller et al., 2011).

Berbagai penelitian juga menunjukkan adanya peningkatan prevalensi hipertrigliserida di negara-negara berkembang. Penelitian di Asia Selatan menunjukkan trend peningkatan kadar trigliserida dan penurunan kadar High Density Lipoprotein/HDL (Baig et al., 2015). Sherpa, et.al., (Sherpa et al., 2011) juga melaporkan bahwa dari 371 sampel berusia 30-70 tahun di Tibet menunjukkan 12,2\% mengalami hipertrigliserida (>150 mg/dl).

Di Indonesia, dilaporkan bahwa ada peningkatan prevalensi penduduk yang memiliki kadar trigliserida tidak normal. Pada tahun 2004 berdasarkan Survei Konsumsi Rumah Tangga (SKRT) prevalensi penderita hipertrigliseridemia (> $200 \mathrm{mg} / \mathrm{dl}$ ) pada usia 25-56 tahun adalah sebesar 1,5\% (Kemenkes, 2005). Dan ditemukan kenaikan pada tahun 2013 berdasarkan Riset Kesehatan Dasar (RISKESDAS) tahun 2013, temuan menunjukkan bahwa kadar trigliserida abnormal pada penduduk 15 tahun sebesar $13,0 \%$ termasuk kategori borderline $(150-199 \mathrm{mg} / \mathrm{dl})$ dan 11,9\% termasuk kategori tinggi dan sangat tinggi
(200-499 mg/dl) (Kemenkes, 2013). Selain itu, Sartika juga melaporkan prevalensi hipertrigliserida sebesar 39,8\% pada pekerja dengan range usia 26,2-54,8 tahun (Sartika, 2011).

Peningkatan kadar trigliserida di usia dewasa menjadi risiko penyakit kardiovaskular. Sebuah studi meta-analisis terhadap penelitian prospektif sebanyak 31 penelitian dengan 132.044 pasien Diabetes Melitus tipe 2 dan 10.733 mengalami penyakit kardiovaskular. Hasilnya menunjukkan bahwa risiko untuk mengalami penyakit jantung sebesar 1,39 kali pada kelompok yang memiliki kadar trigliserida tinggi dibandingkan dengan kelompok yang memiliki kadar trigliserida paling rendah (Ye et al., 2019). Oleh sebab itu penting untuk menjaga agar kadar trigliserida selalu berada pada kadar yang normal agar terhindar dari risiko penyakit kardiovaskular.

Terdapat beberapa faktor yang berhubungan dengan kadar trigliserida. Pertambahan umur menjadi salah satu faktor yang tidak bisa dimodifikasi (Darmawan and Irfanuddin, 2007; Fadila and Isfarudi, 2013). Jenis kelamin juga menjadi faktor yang tidak bisa dimodifikasi (Sherpa et al., 2011; Baig et al., 2015). Status perkawinan juga ditemukan berhubungan dengan kadar trigliserida (Mirmiran et al., 2002).

Sedangkan faktor yang dapat dimodifikasi diantaranya adalah obesitas sentral (Darmawan and Irfanuddin, 2007), merokok (Supriyono et al., 2008; Fadila and Isfarudi, 2013; Wowor, Ticoalu and Wongkar, 2013; Al-Sheyab et al., 2014), aktivitas fisik (Liliany, Jafar and Najamuddin, 2014), dan stress (Boehm et al., 2013) berhubungan dengan kadar trigliserida.

Faktor konsumsi juga merupakan hal yang harus diperhatikan. Konsumsi makan berlemak (Liliany, Jafar and Najamuddin, 2014), konsumsi buah dan sayur (Suwimol et al., 2012) dan kopi (Naidoo et al., 2011) berhubungan dengan kadar trigliserida.

Dari berbagai faktor yang telah disampaikan tersebut, maka penelitian ini menganalisis faktor apa yang lebih utama dan dominan berhubungan dengan kadar 
trigliserida abnormal pada penduduk dewasa di Indonesia.

\section{METODE PENELITIAN}

Jenis penelitian yang digunakan adalah penelitian kuantitatif dengan desain penelitian bersifat analitik dan desain Cross Sectional yaitu seluruh variabel yang diamati diukur pada saat yang bersamaan pada saat pengambilan data RISKESDAS tahun 2013, yang bertujuan untuk mengetahui faktor utama yang berhubungan dengan kadar trigliserida abnormal pada penduduk dewasa di Indonesia.

Bahan yang digunakan dalam penelitian ini adalah hasil penelitian dasar dari Riset Kesehatan Dasar tahun 2013 yang telah dilakukan di seluruh wilayah Indonesia. Sampel dipilih yang memenuhi kriteria inklusi yaitu berusia 26-45 tahun, memiliki data lengkap pemeriksaan trigliserida, dan data lengkap untuk semua variabel penelitian. Total sampel yang diperoleh dari Balitbang Kemenkes adalah 28.300 orang dan yang memenuhi kriteria inklusi adalah 11.373 orang. Jumlah ini memenuhi sampel minimal yang dihitung berdasarkan rumus uji hipotesis beda proporsi berdasarkan penelitian Kustiyah, dkk (Kustiyah, Widhianti and Dewi, 2013) sampel minimal adalah 262, dengan jumlah sampel yang terpilih maka jumlah sampel pada penelitian ini telah memenuhi sampel minimal untuk dilakukan penelitian.

Set data yang diperoleh dari Balitbangkes kemudian diklasifikasikan sesuai dengan standar yang telah ada. Pemilihan variabel disesuaikan antara substansi dengan ketersediaan data di dalam RISKESDAS 2013. Kadar trigliserida dibedakan berdasarkan kriteria yang terdapat di dalam National Cholesterol Education Programme (NCEP) Adult Treatment Panel (ATP)-III 2001 (WHO-Asia Pasific, 2000), dikategorikan abnormal dengan kadar $>150$ $\mathrm{mg} / \mathrm{dl}$, dan lainnya normal. Status menikah dibedakan menjadi hidup sendiri (belum menikah/cerai) dan hidup bersama pasangan (menikah) (Atiku danYusuf, 2011). Dikategorikan obesitas sentral jika lingkar perut $\mathrm{LP} \geq 90 \mathrm{~cm}$ untuk laki-laki and $\mathrm{LP} \geq 80$ $\mathrm{cm}$ untuk perempuan, sesuai yang digunakan Hoppin (Hoppin, 2008) dan rekomendasi Kemenkes (2019).

Kuesioner pola konsumsi juga dikembangkan untuk mengetahui kebiasaan yang dilakukan setiap harinya dalam periode satu minggu. Pola konsumsi makanan berlemak diklasifikasikan menjadi 2 kategori yaitu makan $\geq 3$ kali seminggu dan $<3$ kali seminggu. Klasifikasi ini juga sama dengan variabel pola konsumsi kopi (Kemenkes, 2013) Konsumsi sayur dan buah didefinisikan sesuai anjuran Pedoman Gizi Seimbang (Kemenkes, 2014), dikatakan "adekuat" yaitu mengonsumsi $\geq 5$ setiap hari dalam satu minggu. Merokok dibedakan menjadi "merokok" jika sampel merokok setiap hari atau jarang saat pelaksanaan Riskesdas 2013 (Kemenkes, 2013), dan yang lainnya dianggap "tidak merokok". Aktivitas fisik dikategorikan "aktif" jika sampel melakukan aktivitas berat dan/atau sedang 3 hari dalam seminggu (Kemenkes, 2013). Dan variabel stres dikategorikan "ya" jika sampel menjawab $\geq 6$ pertanyaan dengan jawaban "ya" (Kemenkes, 2013).

Analisis data dilakukan menggunakan perangkat lunak. Uji Chi Square digunakan untuk mengetahui hubungan masing-masing faktor dengan kadar trigliserida, sedangkan Regresi Logistik Berganda model prediksi untuk mengidentifikasi faktor dominan yang berhubungan dengan kadar trigliserida. $\mathrm{P}$ value $\leq 0.05$ dan Confident Interval (95\%) akan diartikan berhubungan secara statistik. Dan faktor dominan dipilih berdasarkan nilai OR pada model akhir.

\section{HASIL DAN PEMBAHASAN}

Dari 11421 subjek penelitian ini, ditemukan bahwa sebanyak 2646 (23,2\%) memiliki kadar trigliserida tidak normal yaitu $>150 \mathrm{mg} / \mathrm{dl}$. Batasan ini sesuai dengan standar populasi yang dianjurkan oleh NCEP III. Berdasarkan karakteristik subjek, diperoleh bahwa lebih dari setengah subjek penelitian berjenis kelamin perempuan $(61 \%)$ dan proporsi subjek yang menikah lebih banyak dibandingkan yang belum 
menikah/cerai. Sebanyak 4346 subjek $(38,1 \%)$ dikategorikan obesitas sentral berdasarkan kriteria Kemenkes pada lingkar perut (Tabel. 1).

Dari segi konsumsi, lebih dari setengah subjek mengonsumsi makanan berlemak $\geq 3$ kali dalam seminggu $(67,2 \%)$. Dan ditemukan bahwa $59,1 \%$ subjek mengonsumsi kopi < 3 kali dalam seminggu. Selain itu, sebagian besar subjek penelitian kurang mengonsumsi sayur dan buah sesuai anjuran dari Pedoman Gizi Seimbang yaitu $\geq 5$ porsi sayur dan buah setiap harinya
(Tabel. 1).

Hasil terkait gaya hidup subjek, lebih dari setengah subjek tidak merokok $(33,6 \%)$ saat penelitian dilaksanakan, sisanya mengaku merokok setiap hari atau jarang selama rentang penelitian Riskesdas 2013 $(33,6 \%)$. Subjek yang kurang aktif $(60,2 \%)$ lebih banyak dibandingkan subjek yang aktif $(39,8 \%)$ melakukan aktivitas fisik dalam seminggu terakhir saat penelitian Riskesdas 2013. Dan hanya sedikit subjek $(5,8 \%)$ yang dikategorikan mengalami stres (Tabel. 1).

Tabel 1. Gambaran Faktor Subjek

\begin{tabular}{|c|c|c|}
\hline Faktor & $\mathrm{N}=11421$ & $\%$ \\
\hline \multicolumn{3}{|l|}{ Kadar trigliserida } \\
\hline Abnormal & 2646 & 23,2 \\
\hline Normal & 8775 & 76,8 \\
\hline \multicolumn{3}{|l|}{ Jenis kelamin } \\
\hline Laki-laki & 4453 & 39,0 \\
\hline Perempuan & 6968 & 61,0 \\
\hline \multicolumn{3}{|l|}{ Status Menikah } \\
\hline Belum menikah/cerai & 1057 & 9,3 \\
\hline Menikah & 10364 & 90,7 \\
\hline \multicolumn{3}{|l|}{ Obesitas sentral } \\
\hline Ya & 4346 & 38,1 \\
\hline Tidak & 7975 & 61,9 \\
\hline \multicolumn{3}{|c|}{ Pola konsumsi makanan berlemak } \\
\hline$\geq 3$ kali per minggu & 7670 & 67,2 \\
\hline$<3$ kali per minggu & 3751 & 32,8 \\
\hline \multicolumn{3}{|l|}{ Pola konsumsi kopi } \\
\hline$\geq 3$ kali per minggu & 4671 & 40,9 \\
\hline$<3$ kali per minggu & 6750 & 59,1 \\
\hline \multicolumn{3}{|l|}{ Konsumsi sayur dan buah } \\
\hline Kurang & 10466 & 91,6 \\
\hline Adekuat & 955 & 8,4 \\
\hline \multicolumn{3}{|l|}{ Merokok } \\
\hline Ya & 3841 & 33,6 \\
\hline Tidak & 7580 & 66,4 \\
\hline \multicolumn{3}{|l|}{ Aktivitas fisik } \\
\hline Kurang Aktif & 6874 & 60,2 \\
\hline Aktif & 4547 & 39,8 \\
\hline \multicolumn{3}{|l|}{ Stres } \\
\hline Ya & 666 & 5,8 \\
\hline Tidak & 10755 & 94,2 \\
\hline
\end{tabular}

Sumber: RISKESDAS, 2013

Rata-rata kadar trigliserida pada subjek penelitian adalah 123, $25 \mathrm{mg} / \mathrm{dl}$ dengan kadar minimum 42 dan maksimum $949 \mathrm{mg} / \mathrm{dl}$. Nilai rata-rata ini 
masih berapa pada kisaran normal, namun hasil pengkategorian subjek berdasarkan kadar trigliserida $>150$ $\mathrm{mg} / \mathrm{dl}$, ditemukan bahwa sebesar $23,2 \%$ subjek termasuk dalam kategori abnormal. Prevalensi ini sedikit dibawah angka nasional yang dilaporkan Riskesdas 2013, yaitu sebesar 24,9\% pada penduduk usia $>15$ tahun. Dibandingkan beberapa penelitian sebelumnya yang mengukur prevalensi hipertrigliseridemia, hasil penelitian ini masih dibawah prevalensi temuan sebelumnya. Ayu (Ayu et al., 2011) menemukan prevalensi hipertrigliserida mencapai $38,4 \%$ di Kuta Bali. Sedangkan, (Sartika, 2011) menemukan prevalensi hipertrigliserida sebesar 39,8\% pada pekerja dengan range usia 26,2-54,8 tahun. Walaupun demikian, besar prevalensi pada penelitian ini sudah cukup besar, dengan perbandingan bahwa satu dari lima penduduk dewasa Indonesia mengalami kadar trigliserida abnormal. Sehingga perlu dilakukan pencegahan dan penanggulangan terhadap faktor-faktor yang berhubungan dengan kadar trigliserida abnormal.

Trigliserida merupakan penyimpan lipid yang utama di dalam jaringan adiposa, bentuk lipid ini akan terlepas setelah dihidrolisis oleh enzim lipase yang sensitif-hormon menjadi asam lemak bebas dan gliserol. Peningkatan asam lemak bebas di darah akan memicu minculnya plak yang dalam menyumbat pembuluh darah. Dari sebuah penelitian dari Emerging Risk Factors Collaboration mengevaluasi 302.430 orang yang bebas dari penyakit pembuluh darah pada awal penelitian. Setelah diikuti dalam penelitian prospektif, diketahui bahwa trigliserida menunjukkan hubungan yang kuat dengan penyakit kardiovaskular dan stroke iskemik, disesuaikan dengan usia dan jenis kelamin. Oleh karena itu, kadar trigliserida yang tinggi sering dihubungkan dengan penyakit kardiovaskular (The Emerging Tisk Factors Collaboration, 2007).

Tabel 2 Hubungan Faktor Subjek dengan Kadar Trigliserida

\begin{tabular}{|c|c|c|c|c|c|c|}
\hline \multirow[t]{2}{*}{ Faktor } & \multicolumn{2}{|c|}{$\begin{array}{r}\text { Trigliserida } \\
\text { Abnormal }\end{array}$} & \multicolumn{2}{|c|}{$\begin{array}{c}\text { Trigliserida } \\
\text { normal }\end{array}$} & \multirow[t]{2}{*}{$\mathrm{P}$} & \multirow[t]{2}{*}{ OR (CI 95\%) } \\
\hline & $\mathrm{N}$ & $\%$ & $\mathrm{~N}$ & $\%$ & & \\
\hline \multicolumn{7}{|l|}{ Jenis kelamin } \\
\hline Laki-laki & 1443 & 32,4 & 3010 & 67,6 & 0,000 & $2,30(2,10-2,51)$ \\
\hline Perempuan & 1203 & 17,3 & 5765 & 82,7 & & \\
\hline \multicolumn{7}{|l|}{ Status Menikah } \\
\hline Belum menikah/cerai & 211 & 20,0 & 846 & 80,0 & 0,010 & $0,81(0,75-0,95)$ \\
\hline Menikah & 2435 & 23,5 & 7929 & 76,5 & & \\
\hline \multicolumn{7}{|l|}{ Obesitas sentral } \\
\hline Ya & 1195 & 27,5 & 3151 & 72,5 & 0,000 & $1,47(1,35-1,61)$ \\
\hline Tidak & 1451 & 20,5 & 5624 & 79,5 & & \\
\hline Pola konsumsi makan & & & & & & \\
\hline \multicolumn{7}{|l|}{ Berlemak } \\
\hline$\geq 3$ kali per minggu & 1717 & 22,4 & 5953 & 77,6 & 0,005 & $0,88(0,80-0,96)$ \\
\hline$<3$ kali per minggu & 929 & 24,8 & 2822 & 75,2 & & \\
\hline \multicolumn{7}{|l|}{ Pola konsumsi kopi } \\
\hline$\geq 3$ kali per minggu & 1181 & 25,3 & 3490 & 74,7 & 0,000 & $1,22(1,12-1,33)$ \\
\hline$<3$ kali per minggu & 1465 & 21,7 & 5285 & 78,3 & & \\
\hline \multicolumn{7}{|l|}{ Konsumsi sayur dan buah } \\
\hline Kurang & 2434 & 23,3 & 8032 & 76,7 & 0,458 & $1,06(0,91-1,25)$ \\
\hline
\end{tabular}




$\begin{array}{lcccccc}\quad \text { Adekuat } & 212 & 22,2 & 743 & 77,8 & & \\ \begin{array}{l}\text { Merokok } \\ \quad \text { Ya }\end{array} & 1233 & 32,1 & 2608 & 67,9 & 0,000 & 2,06(1,89-2,26) \\ \quad \text { Tidak } & 1413 & 18,6 & 6167 & 81,4 & & \\ \text { Aktivitas fisik } & & & & & & \\ \quad \text { Kurang Aktif } & 1594 & 23,2 & 5280 & 76,8 & 0,948 & 1,00(0,92-1,10) \\ \quad \text { Aktif } & 1052 & 23,1 & 3495 & 76,9 & & \\ \text { Stres } & & & & & & \\ \quad \text { Ya } & 148 & 22,2 & 518 & 77,8 & 0,551 & 0,94(0,78-1,14) \\ \quad \text { Tidak } & 2498 & 23,2 & 8257 & 76,8 & & \end{array}$

Tabel 2 menunjukkan hasil uji bivariat antara masing-masing variabel faktor dengan kadar trigliserida, menggunakan uji Chi- Square. Variabel yang memiliki hubungan dengan kadar trigliserida adalah jenis kelamin $(p=0,000)$, status menikah $(\mathrm{p}=0,010)$, obesitas sentral $(\mathrm{p}=0,000)$, pola konsumsi makanan berlemak $(\mathrm{p}=0,005)$, pola konsumsi kopi $(\mathrm{p}=0,000)$, dan merokok $(\mathrm{p}=0,000)$. Sedangkan variabel konsumsi sayur dan buah, aktivitas fisik, dan stres tidak memiliki hubungan dengan kadar trigliserida $((p>0,05)$. Dari Tabel 2 juga diketahui bahwa nilai pvalue dari variabel konsumsi sayur dan buah, aktivitas fisik, dan stres $>0,25$ sehingga tidak dimasukkan dalam uji multivariat model prediksi dengan menggunakan Regresi
Logistik Berganda metode Forward Wald.

Tabel 3 di bawah ini merupakan hasil model akhir dari uji Regresi Logistik Berganda untuk mengetahui faktor yang dominan berhubungan dengan kadar trigliserida. Hasil penelitian menunjukkan jenis kelamin, obesitas sentral dan merokok merupakan tiga faktor risiko dominan yang berhubungan dengan kadar trigliserida (secara berurutan nilai OR 2,745; 2,393; 1,048). Sedangkan variabel status menikah, pola konsumsi makanan berlemak, dan pola konsumsi kopi memiliki nilai OR dibawah satu yang diasumsikan sebagai faktor protektif.

Tabel 3 Hasil Akhir Model Prediksi Faktor Kadar Trigliserida

\begin{tabular}{lrrrcc}
\hline \multirow{1}{*}{ Variabel } & \multirow{2}{*}{$\mathrm{B}$} & \multirow{2}{*}{$\mathrm{p}$} & $\mathrm{OR}$ & \multicolumn{2}{c}{ Tingkat Kepercayaan } \\
\cline { 5 - 6 } & & & & Batas bawah & Batas atas \\
\hline Jenis kelamin & 1,168 & 0,000 & 3,215 & 2,745 & 3,765 \\
Status menikah & $-0,204$ & 0,014 & 0,815 & 0,693 & 0,959 \\
$\begin{array}{l}\text { Obesitas sentral } \\
\text { Pola konsumsi makanan }\end{array}$ & 0,980 & 0,000 & 2,664 & 2,393 & 2,967 \\
berlemak & $-0,100$ & 0,039 & 0,905 & 0,823 & 0,995 \\
Pola konsumsi kopi & & & & & \\
Merokok & $-0,112$ & 0,027 & 0,894 & 0,809 & 0,988 \\
\hline Sunnyyy & 0,201 & 0,011 & 1,222 & 1,048 & 1,426 \\
\hline
\end{tabular}

Sumber: RISKESDAS, 2013

Hasil analisis multivariat menunjukkan bahwa jenis kelamin menjadi faktor dengan nilai OR tertinggi pada penelitian ini, dengan perbandingan bahwa laki-laki memiliki risiko lebih besar dibandingkan wanita. Hasil ini sejalan dengan penelitian dari Baig et al (Baig et al., 
2015) yang menemukan perbedaan yang signifikan antara rata-rata total trigliserida pada laki-laki dan wanita, ditemukan lebih tinggi pada laki-laki usia 18- 45 tahun dibandingkan wanita dengan usia yang sama di Pakistan.

Pada penelitian Sherpa(Sherpa et al., 2011) yang dilakukan di Tibet dengan sampel berusia 30-70 tahun, ditemukan bahwa prevalensi hipertrigliserida tinggi pada laki-laki dan HDL rendah banyak ditemukan pada perempuan. Begitu juga dengan penelitian Fadila dan Isfarudi (Fadila and Isfarudi, 2013) yang menemukan hubungan negatif yang bermakna antara jenis kelamin dengan kadar trigliserida darah yang berarti ratarata kadar trigliserida darah laki-laki lebih tinggi daripada perempuan. Pada penelitian lain juga menunjukkan bahwa kadar trigliserida lebih tinggi pada lakilaki muda dibandingkan dari perempuan, walaupun diketahui lebih rendah pada usia 35-45 tahun, tetapi tetap lebih tinggi dibandingkan perempuan (Darmawan dan Irfanuddin, 2007).

Hasil penelitian ini juga sejalan dengan penemuan dari Lee, et.al, yang menunjukkan bahwa laki-laki mengalami kenaikan kadar trigliserida dari 4 ke 7 jam puasa yang signifikan berhubungan dengan risiko penyakit jantung iskemik. Se- dangkan pada perempuan tidak ditemukan kenaikan yang signifikan (Lee, Koo and Moon, 2019). Perempuan diketahui memiliki kadar trigliserida postprandial dibandingkan laki-laki karena memiliki kapasitas clearance yang lebih tinggi yang disebabkan karena peningkatan aktivitas lipoprotein lipase. Selain itu juga ditemukan bahwa rasio metabolik clearance dari asam lemak pada perempuan lebih tinggi dibandingkan pada laki-laki. Faktor metabolik ini yang menjadi- kan laki-laki berisiko memiliki kadar trigliserida lebih tinggi dibandingkan perempuan (Sarac et al., 2012).

Faktor kedua yang berhubungan dengan kadar trigliserida adalah obesitas sentral, dengan nilai OR sebesar 2,6. Hal ini sejalan dengan penelitian (Darmawan and Irfanuddin, 2007) yang menemukan bahwa obesitas pada bagian abdomen mempunyai pengaruh besar terhadap kadar trigliserida daripada terhadap parameter lipid lainnya. Hubungan positif dan bermakna juga dilaporkan oleh (Fadila and Isfarudi, 2013) bahwa Rasio Lingkar Pinggang Pinggul (RLPP) memiliki hubungan dengan kadar trigliserida. Temuan ini mempertegas bahwa semakin tinggi lingkar pinggang dan pinggul maka akan meningkatkan kadar trigliserida darah. Obesitas abdominal meningkatkan risiko terjadinya gangguan metabolik yang semakin besar, seperti meningkatnya konsentrasi plasma triasilgliserol, glukosa dan insulin, tekanan darah meningkat, dan kadar kolesterol HDL rendah. Kombinasi dari gangguan-gangguan tersebut sering mengarah ke sindrom metabolik. Penimbunan lemak pada jaringan adipose viseral dalam jangka panjang menyebabkan ketidakmampuan sel lemak untuk menyimpan trigliserida secara adekuat. Akibat mekanisme ini dalam jangka panjang menyebabkan terjadinya peningkatan kadar kolesterol dalam darah, kondisi ini merupakan tahap awal terjadinya resistensi insulin. Pada tahap lanjutan dari hipertrigliserida adalah tertimbunnya lemak pada jaringan adipose viseral yang merupakan perlemakan organ-organ dalam perut (Subramanian and Chait, 2012).

Faktor ketiga adalah merokok. Responden yang merokok mempunyai risiko lebih besar untuk memiliki kadar trigliserida tidak normal dibandingkan yang tidak merokok. Hasil penelitian ini juga sejalan dengan penelitian (Wowor, Ticoalu and Wongkar, 2013) yang menemukan bahwa ada perbedaan kadar trigliserida darah pada laki-laki perokok dan laki-laki bukan perokok, laki-laki perokok mempunyai kadar trigliserida yang lebih tinggi daripada lakilaki bukan perokok. Sejalan dengan hal tersebut, (Supriyono et al., 2008) menemukan bahwa sebesar $36,0 \%$ responden yang merokok mengalami hipertrigliserida. 
Begitu juga pada penelitian (Kshitiz, Sinha and Bhattacharjee, 2010) yang menemukan bahwa kadar trigliserida lebih tinggi secara signifikan pada perokok dibandingkan dengan yang tidak merokok dan tergantung pada jumlah rokok dan lamanya merokok. Temuan (Fadila and Isfarudi, 2013) melaporkan bahwa responden yang perokok memiliki proporsi trigliserida darah dengan ukuran 200-499 mg/dl lebih banyak dibandingkan dengan yang tidak merokok. Hal ini dapat disebabkan karena masukan nikotin yang berasal dari asap rokok menyebabkan kadar asam lemak bebas menjadi lebih tinggi sehingga meningkatkan sekresi Very Low Density Lipoprotein (VLDL) oleh hati yang meliputi sekresi trigliserida dan kolesterol serum ke dalam sirkulasi darah (Botham and Mayes, 2009). Kondisi ini akan berlanjut pada usia berikutnya, ditemukan bahwa lansia yang merokok mempengaruhi kadar kolesterol total, lipoprotein A, dan trigliserida. Sedangkan pada usia di bawah 50 tahun, merokok hanya berhubungan dengan kadar trigliserida (Al-Sheyab et al., 2014).

Jika ditelaah jumlah rokok yang dihisap per hari oleh responden, maka diketahui bahwa rata-rata 12,39 batang per hari dengan standar deviasi 6,974, minimal 1 batang dan maksimal 46 batang per harinya. Jumlah batang rokok yang dihisap per harinya dilakukan analisis untuk melihat hubungannya dengan kadar trigliserida. Pada penelitian ini ditemukan adanya perbedaan rata-rata jumlah rokok yang dihisap pada responden dengan kadar trigliserida tidak normal dan yang normal $(\mathrm{p}<0,05)$. Merokok dapat meningkatkan kecenderungan sel-sel darah menggumpal pada dinding arteri, menurunkan jumlah HDL, menurunkan kemampuan HDL dalam menyingkirkan kolesterol LDL yang berlebihan, serta meningkatkan oksidasi lemak yang berperan dalam perkembangan arterosklerosis (Bhat et al., 2008).
Hasil penemuan lainnya pada penelitian ini adalah bahwa faktor lainnya yaitu status menikah, makanan berlemak dan kopi memiliki nilai OR di bawah 0 . Temuan ini masih memerlukan penelitian lanjutan karena diduga hal ini terkait dengan keterbatasan pada penelitian ini. Keterbatasan pertama adalah terkait dengan jumlah variabel yang masuk dalam seleksi adalah variabel yang tersedia di dalam set data RISKESDAS 2013, sehingga diasumsikan ada variabel yang berhubungan namun tidak diteliti pada penelitian ini seperti konsumsi makanan sumber energi, penggunaan hormonal, pen- yakit yang diderita terkait dengan kadar trigliserida dan faktor lainnya. Selain itu, ditemukan adanya proporsi variabel yang sangat dominan pada salah satu kategori seperti aktivitas fisik sebesar $94,2 \%$ penduduk dewasa Indonesia melakukan aktivitas fisik kurang. Begitu juga dengan konsumsi sayur dan buah yaitu sebesar 91,6\% penduduk kon- sumsi sayur dan buah yang kurang. Kurangnya variasi data tersebut dapat menyebabkan tidak ditemukan hubungan secara statistik saat dilakukan uji hipotesis.

\section{KESIMPULAN}

Temuan dari penelitian ini menunjukkan bahwa ditemukan sebanyak $23,2 \%$ responden memiliki kadar trigliserida tidak normal yaitu $>150 \mathrm{mg} / \mathrm{dl}$. Faktor utama yang berhubungan dengan kadar trigliserida tidak normal tersebut adalah jenis kelamin, obesitas sentral, dan merokok. Sehingga disarankan kepada penduduk dewasa untuk menjaga gaya hidup agar tidak mengalami obesitas sentral, utamanya kelompok laki-laki. Selain itu, meninggalkan rokok dengan cara mengurangi jumlah rokok yang dikonsumsi setiap harinya secara bertahap sehingga terjadi penurunan kadar trigliserida yang tidak normal.

\section{REFERENSI}

Al-Sheyab, F. M. et al. 2014. Effects of smoking on lipid profile and homocysteine in coronary heart disease. 
Jordan Journal of Biological Sciences. 7(1): 63-66.

Atiku, M. and Yusuf, A. 2011. Marital Status and Occupation versus Serum Total Cholesterol and HDLCholesterol Levels in Healthy Adults from Kano Metropolis, Nigeria. Bayero Journal of Pure and Applied Sciences. 4(1): 110-111.

Ayu, P. et al. 2011. Prevalensi dan Hubungan Sindrom Metabolik dengan Penyakit Ginjal Kronik pada Populasi Desa Legian, Kuta Bali. Jurnal Penyakit Dalam. 12(2): 103108.

Baig, S. A. et al. 2015. The association of nutritional profile and prognosis of degenerative diseases associated with carbohydrate and lipid metabolism at high altitude of district Ziarat, Pakistan. Saudi Journal of Biological Sciences. 22(1): 50-55.

Bhat, V. M. et al. 2008. Dose-Response Relationship between Cigarette Smoking and Risk of Ischemic Stroke in Young Women. Stroke. 39(9): 2439-2443.

Boehm, J. K. et al. 2013. Relation between Optimism and Lipids in Midlife. The American Journal of Cardiology. 111(10): 1425-1431.

Botham, K. and Mayes, P. 2009. Pengangkutan dan Penyimpanan Lipid' in Biokimia Harper. Edisi $27^{\text {th }}$. EGC. Jakarta-Indonesia.

Darmawan, H. and Irfanuddin, I. 2007. Effect of age and sex on the association between lipid profile and obesity among telecomunication workersin

Palembang. Medical Journal of Indonesia. 16(4): 251.

Fadila, I. and Isfarudi. 2013. Pengukuran Kadar Trigliserida melalui Pendekatan Antropometri. Seminar Nasional FMIPA UNDIKSHA III. 7 Desember 2015, Bali, Indonesia. Hal. 288-295.

Hoppin, A. 2008. Evaluation and Management Obesity in Nutrition in Pediatrics: Basic Science, Clinical
Applications. Edisi 4. PMPH. BostonUSA.

Kemenkes. 2005. Survei Kesehatan Rumah Tangga (SKRT) Tahun 2005. Jakarta.

Kemenkes. 2013. Riset Kesehatan Dasar (RISKESDAS) Tahun 2013. Jakarta.

Kemenkes. 2014. Pedoman Gizi Seimbang. Direktorat Jenderal Bina Gizi dan KIA. Jakarta.

Kemenkes. 2019. Buku Pintar Kader Posbindu. Direktorat Jenderal Pencegahan dan Pengendalian Penyakit Tidak Menular. Jakarta.

Kshitiz, K. K., Sinha, R. B. and Bhattacharjee, J. 2010. A study of effects of smoking on lipid and vitamin C metabolism. International Journal of Pharma and Bio Sciences. 1(4): 106113.

Kustiyah, L., Widhianti, M. and Dewi, M. 2013. Hubungan Asupan Serat dengan Status Gizi dan Profil Lipid Darah pada orang Dewasa Dislipidemia. Journal Gizi dan Pangan. 8(3): 193-200.

Lee, S. Y., Koo, B. K. and Moon, M. K. 2019. Non-fasting triglyceride levels in the Korean population with and without ischemic heart disease and cerebrovascular disease. Korean Journal of Internal Medicine. 34(2): 353-364.

Liliany, E. I., Jafar, N. and Najamuddin, U. 2014. Hubungan Aktivitas Fisik dan Pola Makan terhadap Komponen Sindrom Metabolik pada Pasien Rawat Jalan DM Tipe 2 di Wilayah Kerja Puskesmas Kota Makassar. Fakultas Kesehatan Masyarakat Universitas Hasanuddin, Makassar.

Miller, M. et al. 2011. Triglycerides and cardiovascular disease: A scientific statement from the American Heart Association Circulation. 123(20): 22922333.

Mirmiran, P. et al. 2002. Association of Educational Level and Marital Status with Dietary Intake and Cardiovascular Risk Factors in Tehranian adults: Tehran Lipid and Glucose Study (TLGS). Nutrition Research. 22(12): 1365-1375. 
Naidoo, N. et al. 2011. Cholesterolraising diterpenes in types of coffee commonly consumed in Singapore, Indonesia and India and associations with blood lipids: A survey and cross sectional study. Nutrition Journal. 10(1): 48.

Sarac, I. et al. 2012. Gender differences in VLDL1 and VLDL2 triglyceride kinetics and fatty acid kinetics in obese postmenopausal women and obese men. Journal of Clinical Endocrinology and Metabolism. 97(7): 2475-2481.

Sartika, R. 2011. Effect of Trans Fatty Acids Intake on Blood Lipid Profile of Workers in East Kalimantan, Indonesia. Malaysian Journal of Nutrition. 17(1): 119-127.

Sherpa, L. Y. et al. 2011. Lipid profile and its association with risk factors for coronary heart disease in the highlanders of Lhasa, Tibet. High altitude medicine \& biology. 12(1): 57-63.

Subramanian, S. and Chait, A. 2012. Hypertriglyceridemia secondary to obesity and diabetes. Biochimica et Biophysica Acta - Molecular and Cell Biology of Lipids. 1821(5): 819825.

Supriyono et al. 2008. Faktor-Faktor Risiko Kejadian Penyakit Jantung
Koroner (PJK) Pada Kelompok Usia $<45$ Tahun (Studi Kasus di RSUP Dr. Kariadi Semarang dan RS Telogorejo Semarang). Program Pascasarjana, Universitas Diponegoro.

Suwimol, S. et al. 2012. Impact of Fruit and Vegetables on Oxidative Status and Lipid Profiles in Healthy Individuals. Food and Public Health. 2(4): 113-118.

The Emerging Tisk Factors Collaboration. 2007. The Emerging Risk Factors Collaboration: analysis of individual data on lipid, inflammatory and other markers in over 1.1 million participants in 104 prospective studies of cardiovascular diseases. European Journal of Epidemiology. 22(12): 839869.

WHO-Asia Pasific. 2000. The Asia-Pacific Perspective: Redefining Obesity and its Treatment. Health Communications Australia Pty. Australia.

Wowor, F. J., Ticoalu, S. and Wongkar, D. 2013. Perbandingan Kadar Trigliserida Darah Pada Pria Perokok dan Bukan Perokok. Jurnal e-Biomedik. 1(2): 986990.

Ye et.al. 2019. Serum triglycerides as a risk factor for cardiovasular diseases in type 2 diabetes mellitus: a systematic review and meta-analysis of prospective studies. Cardiovascular Diabetol. 18(48): 1-10. 